\title{
Research on Coupling Factors of the Marxism Subjectivity Thought
}

\author{
WangXiaofeng \\ Nanchang Institute of Science \&Technology,Nanchang 330108,China
}

\begin{abstract}
Keywords: subjectivity thought; Marxism; Coupling factors; Countermeasure model
\end{abstract}
\begin{abstract}
Through researches we conducted, we know that college subjectivity thought Marxism is be able to adhere to the concept of people-oriented and wants to take advantage of the latest theories of Marxism in China, and armed the majority of young people's minds to mobilize young students their own enthusiasm and innovative natural and rich youth student life. Moreover, it strengthens ideological and political research activities of the young students in order to keep the crucial point of the ideological and political quality and level of education, makes in-depth and regularly carry out among youth, and conducts ideological and political status of research to master the relevant coupling factor transform data and scientific decision-making model in order to further promote Marxism work.
\end{abstract}

\section{Introduction}

subjectivity thought is the demonstrated ability of the people in the course of practice, role, status, autonomy, initiative, dynamic, free status and characteristics of destination activities. subjectivity thought Marxism is comprehensive to target the students as the main body and to stimulate students' awareness of autonomous learning and the development of the student's body. subjectivity thought motivates students' healthy and comprehensive development of the target, and improves the comprehensive quality of students as well as the students' independent personality and free spirit, shaping students spirit of human dignity and developing the students' self-fulfilling attitude to life. It guides the students to combine theory with practice, tests themselves in practice, and encourages students to establish the correct values and outlook on life. It enables them to stand firm in the current world with excellent integrated literacy, high moral character , integrity and expertise, and be able to take up the cause of socialism with the succession and the important task of the persistent quest ability and spirit of research. subjectivity thought political education allows students to have a clear understanding, while the Marxism is not just an educational process, but is a practice of self-life practice process. Objective needs to strengthen and improve ideological and political work and also comprehensively improves the inherent requirements of the contemporary youth literacy[1].

\section{Analysis of the current status of subjectivity thought Marxism}

For a better, overall, and clear understanding of young people's ideological position, a survey was conducted to provide the scientific basis for the Marxism in analysis. I conducted a questionnaire survey of college students of different schools of higher education, mainly to understand the Marxism of the students' main manifestation of learning. After the survey we carried out more scientific statistics. The survey points use open stratified multi-stage sampling method, in accordance with the proportion of students of the various colleges and universities and professional distribution; we take a random method of extraction with the total issued 5,000 copies of the questionnaire[2]. We took back 4678 questionnaires in which there were 4560 valid questionnaires with efficiency reaching $91.2 \%$. We took 2000 from the 4678 questionnaires as the sample, of which 1,800 valid questionnaires with each sex and the survey object data Table is as follows. 
Tab.1 Object questionnaire data Table

\begin{tabular}{|l|l|l|l|l|l|l|}
\hline \multicolumn{2}{|l|}{} & $\begin{array}{l}\text { Vocationa } \\
\text { 1 school }\end{array}$ & $\begin{array}{l}\text { Ordinary } \\
\text { second } \\
\text { degree } \\
\text { colleges }\end{array}$ & $\begin{array}{l}\text { Ordinary } \\
\text { third degree } \\
\text { colleges }\end{array}$ & $\begin{array}{l}\text { Ordinary } \\
\text { first } \\
\text { degree } \\
\text { colleges }\end{array}$ & $\begin{array}{l}\text { Effective } \\
\text { amount }\end{array}$ \\
\hline \multirow{2}{*}{ Boys } & $\begin{array}{l}\text { The number } \\
\text { of students }\end{array}$ & 256 & 244 & 217 & 233 & 900 \\
\cline { 2 - 7 } & Ratio\% & 12.80 & 12.20 & 10.85 & 11.65 & 45 \\
\hline Girls & $\begin{array}{l}\text { The number } \\
\text { of students }\end{array}$ & 203 & 219 & 247 & 231 & 900 \\
\cline { 2 - 7 } & $\begin{array}{l}\text { Ratio\% } \\
\text { The number } \\
\text { of students }\end{array}$ & 10.15 & 10.95 & 12.35 & 11.55 & 45 \\
\cline { 2 - 7 } & Ratio\% & 22.8 & 23.15 & 23.20 & 23.20 & 90 \\
\hline
\end{tabular}

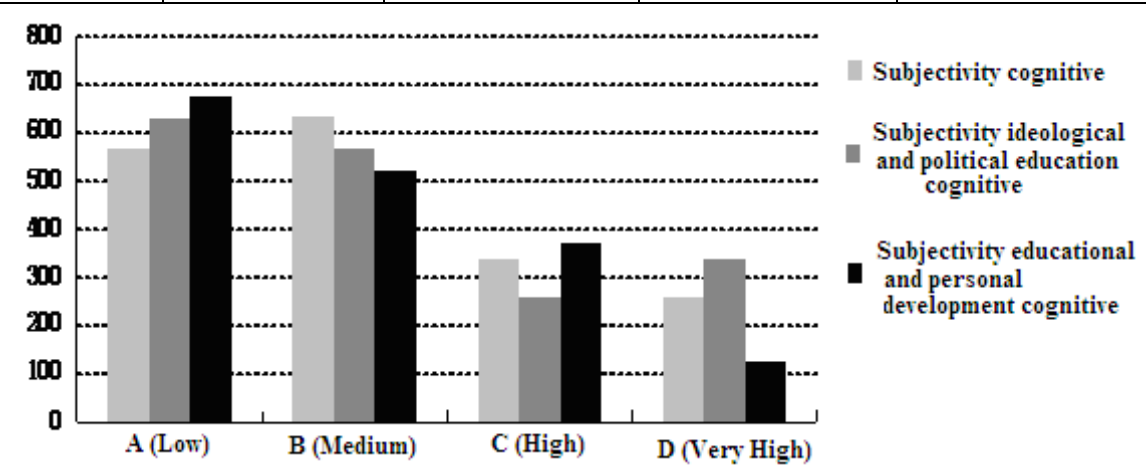

Fig.1 Cognitive survey of subjectivity thought Marxism

Through the statistical structure results in Table 1, we can see that boys and girls each accounted for $50 \%$, the effective ratio of the vocational and technical schools accounted for $22.8 \%$. The effective ratio was $23.15 \%$ for the ordinary third institutions; $23.20 \%$ for the second and $23.20 \%$ for the first. Questionnaire surveys in different categories of institutions of higher education are different in terms of the distribution from the data structure, and the proportion of students are basically about $20 \%$, in line with the average distribution rules. The survey results can represent the current state of young people's ideological and political ideas. Survey of the main political education cognitive reactions of each class of students is not the same, specifically shown in Figure 1.

As is shown in Figure 1, the entire survey found that young college students' self-awareness is relatively low, regardless of which colleges the students are from, and only a small part of them have a clear notion of how important subjectivity thought education is and the all-round development of their own is very necessary. Now more than two-thirds of the students are not able to clear the autonomy of the ideological and political as well as subjectivity thought education for the overall development of students and individuals to achieve practical significance. In order to better provide a scientific basis for the autonomy of the Marxism with the coupling factor and countermeasures model, multi-angle survey was conducted related to the student's political beliefs, moral values, current affairs, policy learning, work status, mental status, living conditions, and many other investigations, which are specifically shown in Table 2. 
Table 2 coupling factor survey on college students’ subjectivity thought Marxism

\begin{tabular}{|c|c|c|}
\hline Types & Items & Proportion \\
\hline \multirow{4}{*}{ Political beliefs } & Belief in communist ideals & $83.5 \%$ \\
\hline & Common ideal of socialism with Chinese characteristics & $91.14 \%$ \\
\hline & Adhere to the reform and opening up & $93.2 \%$ \\
\hline & $\begin{array}{l}\text { Socialist core value system and the scientific concept of } \\
\text { development }\end{array}$ & $87.0 \%$ \\
\hline \multirow{4}{*}{ Moral concepts } & Willing to sacrifice, blood donation & $80.1 \%$ \\
\hline & Hard work, plain living, and pragmatic & $82.2 \%$ \\
\hline & Mainstream moral values approval & $79.8 \%$ \\
\hline & Socialist concept of honor and Zhixing & $75.4 \%$ \\
\hline \multirow{3}{*}{$\begin{array}{l}\text { Events and } \\
\text { policies }\end{array}$} & Events and policies people often concerned about & $65.4 \%$ \\
\hline & Concerns & $49.6 \%$ \\
\hline & Non-concerns & $13.7 \%$ \\
\hline \multirow{3}{*}{$\begin{array}{l}\text { Learning and } \\
\text { employment }\end{array}$} & Targeted learning, and combing theory and realities & $59.9 \%$ \\
\hline & Focus of interest in training and further education & $39.8 \%$ \\
\hline & Blind, fuzzy, and following the trend & $57.3 \%$ \\
\hline \multirow{4}{*}{$\begin{array}{l}\text { The living } \\
\text { psychology }\end{array}$} & Most of the time on the Internet & $46.7 \%$ \\
\hline & The pressure of life and practice less & $56.9 \%$ \\
\hline & UnsTable emotional life, and a life of troubles & $54.7 \%$ \\
\hline & $\begin{array}{l}\text { Hope to participate actively psychological ideological } \\
\text { education }\end{array}$ & $67.8 \%$ \\
\hline
\end{tabular}

As is shown in Table 2, today's college students' ideological and political sensitivity is very high. More than $80 \%$ of the students have a firm political belief; more than $75 \%$ of the students with correct moral values agree with the mainstream moral values; the vast majority of students focus on politics; only $13.7 \%$ of the students are not concerned about the current political. In learning and employment, half of the students appears blind, fuzzy, and following suit, but most of the students with clear objectives are not optimistic[3]. College students have more psychological problems of life now while $46.7 \%$ percent of students living in the Internet, but more than $50 \%$ of the students believe that the time is too short.

The integrated survey found strong collision with the deepening of China's reform and opening up, like the traditional Chinese culture and western culture, the young students' ideas, value, ways of thinking, behavior, psychological undergone profound changes, diversified values and complex characteristics. So many students have not yet completed the stability of the formation of the concept of the value of life, the growing multi-contradictory characteristics and the development trend began to negative factor in the value orientation of young students, particularly individual students with strong egoism and serious misunderstanding the values of individualism and utilitarian thinking, putting too much emphasis on their own personal gains and losses, but neglecting social, the collective, the collective pride and collective cohesion. They secularized in the pursuit of life, and utilitarian is becoming more prominent. In short, the current values of college students are coexistent with each other.

\section{Analysis of coupling factors and countermeasures model}

In recent years, the state has increased the intensity of the Marxism. Main countries adapted to the talent needs of modernization, and expanded the size of the college and university admissions, sources and composition of college students more complex individual student performance 
distinctive, both embodies good, there are a large number of inadequate emerging. College students' mental outlook and values as well as the behavior of quasi-side are undergoing great changes, both positive and negative. With the development of social and cultural life, spiritual life of people has become rich. Then the further deepening of reform and opening up also makes the world faces a variety of cultural thinking[4]. The influx of domestic bad ideology also appears in the behavior of young people. It is these changes in the Marxism has brought new challenges. We want to change the Marxism thinking, strengthen the education of the students of the main cognitive digging coupling factor in the process of teaching and related mathematical model, so that we can establish countermeasures model and play an educational function,

Factor principal component analysis is conducted on coupling factor and countermeasures model subjectivity thought political education with the research methods. In order to obtain the full coupling factor information and that it appears the problem reliably inferred in the Marxism, we tend to observe and select multiple coupling factor as a variable coupling factor that reaches a dozen or dozens of different factors in different degrees reflecting problems of the students who, in the course of the study, have to select important factor indicators to obtain the status of student information. But in most of the time, the relationship between these factors can be interpreted as the overlap of the two coupling factor reflecting the information from the mathematical model, for all the variables (coupling factors) are comprehensive and integrated into several aspects or several factors, such as in political beliefs, moral concepts, events and policies, learning status, work status, mental status, living conditions, and so on. We set to $\mathrm{m}, \mathrm{m}<\mathrm{n}$, requiring $\mathrm{m}$ and comprehensive variable (coupling factor) can fully reflect the original $n$ variables factor information, but also be able to make it does not occur between the $\mathrm{m}$ coupling factor. And the basic idea of the model of the coupling factor and countermeasures original have a certain the coupling of the Marxism factor reassembled into a new set of cross-correlation information to reflect the students' ideological and political situation. We assume that the random vector is $X=\left(x_{1}, x_{2}, \ldots, x_{n}\right)$, and we coordinate transformation of the original variables (factors)[5]:

$$
\begin{aligned}
& z_{1}=\mu_{11} x_{1}+\mu_{21} x_{2}+\ldots+\mu_{n 1} x_{n} \\
& z_{2}=\mu_{12} x_{1}+\mu_{22} x_{2}+\ldots+\mu_{n 2} x_{n} \\
& \cdot \\
& \cdot \\
& z_{n}=\mu_{1 n} x_{1}+\mu_{2 n} x_{2}+\ldots+\mu_{n n} x_{n}
\end{aligned}
$$

This requires that $\mu_{1 k}^{2}+\mu_{2 k}^{2}+\ldots+\mu_{m k}^{2}=1$, wherein $\mathrm{k}=1,2, \ldots \mathrm{m}$;

$\operatorname{cov}\left(z_{i}\right)=U_{i}^{\prime} D(x)=U_{i}^{\prime} D(x) U_{i}, \operatorname{cov}\left(z_{i}, z_{j}\right)=U_{i}^{\prime}(x) U_{j}$;in which $\mathrm{i}, \mathrm{j}=1,2, \ldots, \mathrm{m}$; if $z_{1}=u_{1}^{\prime} x$, which meets[6]:

(1) $u_{1}^{\prime} u_{1}=1$,

(2) $\operatorname{var}\left(z_{1}\right)=\max \operatorname{var}\left(u^{\prime} x\right)$,

then we can say that $z_{1}$ is the major component in $x$,if $z_{1}$ is inadequate to represent the information contained in the original variable factor, then we consider using $z_{2}, z_{2}$ to meet[7]:

(1) $\operatorname{cov}\left(z_{1}, z_{2}\right)=0$;

(2) $u_{2}^{\prime} u_{2}=1$;

(3) $\operatorname{var}\left(z_{1}\right)=\max \operatorname{var}\left(u^{\prime} x\right)$,

then $z_{2}$ is the second main component. The main component of teaching significance is analyzed from the ratio of the size of the coefficient of coupling factor, the larger the absolute value of the ratio of the coefficients, indicating the variable (coupling factor ) has a large absolute value of the variable. The positive sign represents the same variables and the actively acting direction, and the negative sign indicates a negative direction of action of the same. If the research result of distribution of the 
statistical rules through the integrated variables (coupling factor) and the distribution of feature vectors of the values of each component can make space for comparative analysis.

The model allows the coupling factor and countermeasures model study of the subjectivity thought political education to make the students have comparability between individuals, and standardized indicators of individual students in each student monomer components analysis process treatment, making the students of different situations (different metrics) convert the same indicators measure to eliminate the difference between each student's grade. The students' ideological and political situation has comparability and encourage. And through orthogonal political education transform we are looking consolidated variables indexes to overcome the correlation between the original variable indicators, which is more comprehensive. In the process of evaluation of political education, we determine weigh is objective and reasonable and overcome defect in the other evaluation methods' artificial weights.

\section{Discriminant analysis of the countermeasure model based on the coupling factors}

Discriminant analysis based on the countermeasures model coupling factor is judged according to the sensing variable study sample (students' ideological and political situation) of how to classify the multivariate statistical analysis model method. We create a group of other prediction mode for each individual student to observe, and based on the linear combination of survey variables (coupling factor) to produce a series of discriminant function discriminant function of these predictors, which can fully reflect the ideological and political conditions of each individual student, and the differences between them in a series of process analysis. Discriminant function fitting out the foundation of the state of mind of each individual student, and generating function is able to run for the observation point variable sample points (middle), and further determine the student category.

In a $\mathrm{P}$ environment, there are $\mathrm{K}$ known individual students $G_{1}, G_{2}, \ldots, G_{i}$, while coupling factor weighting coefficient $X\left(x_{1}, x_{2}\right.$, ..., $x_{p}$ ), which belongs to K's overall consolidated variable factor of a variable discriminant analysis to resolve the ideological and political position of the sample point (individual student), and discriminant $\mathrm{x}$ belongs to which category and it is positive or negative[8].

Weights of information are determined in the process of conducting relevant factor to convert the weight when necessary for each class of students' ideological and political situation in the beginning. In the process of analysis of the ideological and political situation of the individual students' coupling factor distribution density function, we also should know individual students between sample points belong to the probability of each feature to facilitate the establishment of an appropriate discriminant rules by analyzing the sample points. They belong to the largest of which are within the scope of probability and minimum probability proportional to further determine the individual student predicted class attribution, when the discriminant score of a student is A, then the probability of belonging to the i-th class:

In the formula $P\left(G_{i} \mid D\right)=\frac{P\left(D \mid G_{i}\right) \bullet P\left(G_{i}\right)}{\sum P\left(D \mid G_{i}\right) \bullet P\left(G_{i}\right)}, P\left(G_{i}\right)$ is the priori probability, and $P\left(D \mid G_{i}\right)$ is the conditional probability discriminant score $\mathrm{A}$ in the $\mathrm{i}$-th students to determine a student belongs to a category[9]. And we need to determine the coupling factor probability of the students is the largest; so that the students can make the ideological and political predictive views of the situation.

\section{Conclusion}

Subjectivity thought education embodies the basic requirements of Marxism and has a profound meaning to improve Marxism effectiveness. Through practical experience in the field of Marxism, research experience with the actual investigation, and a combination of theory with practice, the author researches on coupling factor of subjectivity thought Marxism and the actual situation, with 
the use of factor principal component analysis to establish countermeasures model and makes in-depth study and optimization of the Marxism teaching science concepts and strategies.

\section{References}

[1] Teng Jianyong. Research exploration of graduate of party building and ideological and political work [M]. Shanghai University Press, 2009:422.

[2] Zhang Tianbao. subjectivity thought Education Cultural Communication practice [M] Beijing: Education Science Press, 2010:147-151.

[3] Zhang Yaocan. The forefront of the Marxism [M] Beijing: People's Education Publishing House ,2009:385-390.

[4] Wang Zhongqiao. Marxism of the subjectivity thought of modern beyond ideological education research [J].Journal of Southwest Forestry University, 2011(6):37-40

[5] Chen Jinming. On the modern construction of the main political education [J]. Shanxi Social Science, 2010,16 (5):125-127

[6] Zhang Jianqiang, Li Hengchuan. Ethical dilemmas of the Marxism in the context of globalization [J]. Higher Education Research,2012 (6):52-55.

[7] Zhang Jia. Main political education and traditional Marxism comparative study [J]. Unions Expo: theoretical studies .2011 (10):39-42.

[8] Wu Bin. subjectivity thought effectiveness of Marxism of people learn to reflect on education and vocational [J].Journal of Jinan University,2011 (7):59.

[9] Wei Shiyi. University moral education classes on how to move towards the main resistance [J]. Higher Education Research, 2009 (1):103-105. 